\title{
Selective Estrogen Receptor Degrader AZD9496
}

National Cancer Institute

\section{Source}

National Cancer Institute. Selective Estrogen Receptor Degrader AZD9496. NCI

Thesaurus. Code C122834.

An orally available selective estrogen receptor degrader (SERD), with potential antineoplastic activity. Upon administration, SERD AZD9496 binds to the estrogen receptor (ER) and induces a conformational change that results in the degradation of the receptor. This prevents ER-mediated signaling and inhibits the growth and survival of ERexpressing cancer cells. 